\title{
ASAL USUL BAHASA ARAB
}

\author{
Husni M ubarak
}

\begin{abstract}
Abstrak
Bahasa A rab merupakan salah satu cabang dari sekian banyak cabang bahasa Semit yang telah berkembang sejak ribuan tahun. Bahasa A rab muncul sebagai bahasa yang berdiri sendiri, karena salah satu dari pengguna bahasa Semit awal melakukan perpindahan ke daerah-daerah lainnya, Ialu membentuk bangsa sekaligus bahasa. Proses evolusi yang terjadi dalam pergolakan bahasa Arab dengan bahasa-bahasa setempat menjadikan bahasa A rab asli menjadi bermacam-macam dialek. Bahasa A rab dapat tumbuh berkembang serta berdiri sendiri, disebabkan oleh beberapa faktor pendukung salah satunya adalah pergaulan dan percampur-bauran antara bangsa-bangsa.
\end{abstract}

\section{Pendahuluan}

Bahasa pada hakekatnya merupakan alat untuk menyampaikan buah pikiran dan perasaan kepada orang lain, apakah itu berupa bunyi ataupun berupa tulisan. Setiap bahasa memiliki ciri-ciri khas masing-masing yang membedakan dengan bahasa lain, baik dari segi tata bahasanya maupun dari segi kuantitas masyarakat penuturnya.

B ahasa A rab sebagai salah satu bahasa mayor di dunia memiliki setumpuk keistimewaan dari ciri khas tersendiri yang membedakan dengan bahasa yang lainnya. ${ }^{1}$ B ahasa A rab sebagaimana bahasa-bahasa lain memiliki asal-usul sejarah dan perkembangan. Bahasa A rab mula-mula berasal, tumbuh dan berkembang di Negara-negara kawasan timur tengah.

Perkembangan selanjutnya menunjukkan bahwa pengaruh bahasa Arab

\footnotetext{
${ }^{1}$ Bahasa A rab dituturkan lebih dari 200 juta ummat manusia yang tersebar kurang lebih di 20 negara, lihat A zhar A rsyad, Bahasa A rab dan Metode Pengajarannya, Beberapa Pokok Pikiran. (Fak. Tarbiyah IA IN A lauddin U jung Pandang, 1997), h. 1-2.
} 
tampak semakin luas dalam pergaulan dunia internasional, sehingga sejak tahun 1973 bahasa ini diakui secara resmi sebagai bahasa yang sah untuk dipergunakan di lingkungan Perserikatan Bangsa-Bangsa. ${ }^{2}$ B ahasa A rab juga dianggap bahasa umat Islam, disebabkan dengan adanya al-Qur' an dan hadis Nabi yang berfungsi sebagai dua sumber pokok ajaran Islam ditulis dalam bahasa A rab, ${ }^{3}$ bahkan tidak terbatas pada dua sumber itu. ${ }^{4}$ A pa yang kita lihat dan baca dalam al-Qur'an dan hadis, berikut buku-buku agama sebagai hasil dari interpretasi rujukan utama Islam yang semuanya menggunakan bahasa Arab dalam mengkomunikasikan pesan-pesan religiusnya, ternyata telah melalui proses evolusi dalam kurun waktu sejarah perjalanan bahasa Arab sebagaimana yang dipakai sekarang tidak sama dengan bahasa A rab qadiim disaat awal munculnya, tapi telah melalui perjalanan panjang selama ribuan tahun yang berproses sedikit demi sedikit hingga mencapai kesempurnaan seperti terlihat pada bahasa al-Qur'an dan bahasa Fushah yang dijadikan sebagai alat komunikasi.

Perubahan tersebut terjadi di saat suatu pemakai bahasa berpindah ke tempat lain sekaligus menetap dan beranak pinak lalu berbaur dengan bahasa lain, di situ terjadi proses perubahan step by step tanpa dirasakan oleh sipemakainya dan begitulah seterusnya.

\footnotetext{
${ }^{2}$ Chatibul Umam, A spek-aspek Fundamental Dalam Bahasa A rab (C et. 1; Bandung: PT alMa'arif, 1980), h.15.

${ }^{3}$ L ihat misalnya, QS. Y usuf 12:2, QS. A I-Zumar 39:28 dan ayat lainnya. A yat-ayat tersebut hanya berbicara tentang A lquran yang diturunkan dalam bahasa A rab. Sedangkan hadis Nabi tidak dijelaskan secara tersurat bahwa hadis itu berbahasa A rab, namun sejarah membuktikan bahwa hadis $\mathrm{Nabi}$ yang dikumpulkan oleh para pengumpul hadis, ditulis dengan bahasa Arab sebab Nabi mengucapkannya dengan bahasa A rab.

${ }^{4}$ Sumber-sumber lain yang dimaksud oleh penulis adalah Fikhi, Tauhid, Tafsir, Filsafat Islam dan berbagai literatur yang ditulis dalam bahasa A rab.
} 
Bahasa Arab menurut para mu'arrikh dan linguist berasal dari satu ras manusia dan rumpun bahasa yang mempunyai peran besar dalam sejarah peradaban kuno yakni bangsa Semit. Kemudian keturunan mereka berpindah tempat meninggalkan tanah airnya dan menetap dilembah sungai Tigris dan Euphrat membentuk rumpun bahasa dan bangsa baru, ${ }^{5}$ seperti Babilonia, Assyiria, Ibrani, Armia, Tunisia dan lain-lain. ${ }^{6}$ Pergulatan antara bahasa pun terjadi saling mempengaruhi dan mengalahkan, bahasa-bahasa yang dominan pemakai dan pengaruhnya yang keluar sebagai pemenang, maka bahasa dari suku itulah yang menjadi bahasa standar, seperti bahasa A rab.

\section{Pembahasan}

\section{A sal-U sul Bahasa A rab}

Salah satu pembahasan pokok dalam bahasa A rab ialah pembahasan tentang latar belakang munculnya bahasa tersebut. Dengan pembahasan seperti itu, kita dapat mengetahui dari mana asal usul bahasa yang tentu dengan sendirinya harus mengetahui sejarah perjalanannya sampai menjadi satu bahasa yang berdiri sendiri demikian halnya dengan bahasa A rab, tidak langsung menjadi satu satu bahasa yang terpisah dari lainnya, akan tetapi mengalami proses yang cukup panjang mulai dari asal bahasa tersebut.

B ahasa A rab merupakan rumpun dari bahasa Semit dan mempunyai anggota penutur yang terbanyak. Bangsa Semit berikut bahasanya dinisbahkan dari putra

\footnotetext{
${ }^{5}$ K. Ali. "A Study of Islamic History", diterjemahkan oleh G hufran A . M as' adi dengan judul Sejarah Islam dari A wal Hingga R untuhnya Dinasti Usmani, Tarkh Pra Moderen, ed I (Cet. I; J akarta: Raja Grafindo Persada, 1997), h. 1.

${ }^{6}$ Philip K. Hitti, "The A rab Short History", diterjemahkan oleh U shuluddin Hutagalung dan O.D.P. Sihombing dengan judul Dunia A rab (Cet. III; B andung: Sumur Bndung, t.th), h. 7.
} 
Nabi Nuh yang bernama Sam ibn Nuh. Garis keturunan Sam inilah yang melahirkan berbagai bangsa dan bahasa, di antaranya bangsa 'A kkadiyyah, Kan'an, Ethopiah, A rab dan sebagainya. ${ }^{7}$ Namun seiring dengan perjalanan umat manusia dari sekian rumpun bahasa Semit, yang tersisa sampai sekarang hanyalah bahasa A rab, bahasa yang telah memberi pengaruh yang cukup besar dalam sejarah peradaban umat manusia, terutama disaat memasuki abad ke VI masehi.

Menurut para ahli, bahwa bahasa-bahasa di dunia yang jumlahnya diperkirakan hampir 3000 bahasa, paling baik dikelompokkan dengan teori yang berdasarkan hubungan kekerabatan yaitu rumpun bahasa Indo-Eropa, Semit-Hemit dan Turania. ${ }^{8}$

Bahasa-bahasa yang termasuk kedalam rumpun bahasa Indo-Eropa dikelompokkan menjadi bahasa India, bahasa Iran, bahasa $Y$ unani, bahasa Prancis, Spanyol, Portugis, Italia Rumania, bahasa Inggris, Belanda, Jerman, Denmark, A rmania, A lbania dan lain-lain.

Sedang bahasa-bahasa yang termasuk rumpun bahasa Semit dan cabang bahasa-bahasa Hemit. Bahasa-bahasa Semit dapat dibagi menjadi dua bahagian, yaitu bahasa Semit Utara, yang terdiri dari bahasa-bahasa Akkadiyah, bahasa B abilonia, bahasa K an'an dan bahasa-bahasa A ramiah. Sedang bahasa Semit selatan terdiri bahasa mesir (Mesir kuno dan koptik), bahasa-bahasa Barbar yang dipergunakan penduduk asli A frika Utara, seperti Tunisia, Aljasair, M aroko, Sahara

${ }^{7}$ Chatibul Umam et.el. Pedoman Pengajaran Bahasa A rab Pada Perguruan Tinggi Agama IA IN (J akarta Proyek Pengembangan Sistem Pendidikan A gama RI, 1975), h. 47, lihat juga B ambang Y udi Cahyono, Kristal-K ristal IImu Bahasa (Cet. I; Surabaya: A irlangga University Press, 1995), h. 379.

\footnotetext{
${ }^{8}$ M ulyanto Sumardi et.el, Pedoman Pengajaran Bahasa A rab Pada Perguruan Tinggi A gama Islam IA IN (J akarta: Proyek Pengembangan Sistem Pendidikan A gama, Departemen A gama RI, 1975), h. 29.
} 
dan sekitarnya serta bahasa Kusyitik, yaitu bahasa penduduk asli bagian timur A frika seperti bahasa Somalia, Galla, B edja, D ankali, A gaw, A far, Sidama dan lainlain.

A dapun rumpun bahasa Tarania meliputi kelompok -kelompok bahasa, yaitu bahasa-bahasa Tunisia yang terdiri dari bahasa Turki, Mongolia dan Manmair, bahasa J epang, bahasa Cina, bahasa K orea, K aukasia, bahasa Sudan, bahasa M elayu Polinesia (termasuk bahasa Indonesia). ${ }^{9}$

B erbagai macam bahasa yang telah disebutkan diatas sebenarnya berasal dari satu bahasa. Hal tersebut menunjukkan bahwa bangsa-bangasa yang mengucapkannya juga berasal dari satu keturunan. Hanya saja berpisah antara satu dengan yang lainnya dan membentuk satu bangsa. Dengan perpisahan antara satu dengan yang lainnya, mengakibatkan pembentukan bahasa pergaulan tersendiri yang sudah tidak persis sama dengan bahasa induknya. A kan tetapi hal itu pun tentu dengan proses yang panjang.

Begitu pula perpisahan bahasa A rab dengan induknya menjadi bahasa yang berdiri sendiri tidak terjadi begitu saja tanpa dengan proses, tapi dengan proses yang panjang. Pertama mungkin dengan pemisahan salah satu keturunan bangsa Semit yang menjelajah kewilayah jazirah yang bertujuan untuk memperlas wilayah kekuasaanya, kemudian proses selanjutnya terbentuklah kebudayaan yang lain yang sudah berada dengan bangsa pertama yang akhirnya tercipta alat komunikasi yang tampaknya berbeda dengan bahasa aslinya. Sejarah pembentukan bahasa adalah proses kata dan kalimat selama beberapa abad, kata yang satu mungkin ssaja tidak terpakai selanjutnya hilang dan digantikan oleh kata baru, apakah itu serapan atau

9 /bid., h. 30. 
terbentuk dari proses perbedaan dialek antara suku atau bangsa pengguna bahasa arab itu. B egitu pula seterusnya hingga terbentuk bahasa A rab seperti sekarang ini.

\section{Perkembangan B ahasa A rab}

Penamaan bahasa yang bersumber dari bahasa Semit sebenarnya muncul dengan kemunculan bangsa-bangsa yang berasal dari keturunan bangsa Semit itu sendiri, maka muncullah bahasa-bahasa 'A kkadiyah( A bad XX SM) yaitu bahasa yang dipergunakan oleh bangsa A syuriah dan Babilonia, Bahasa-bahasa A ramiyah (A bad IX SM ) dan A bbariyah ( sebelum abad XX SM ) Finikiyah (A bad XII SM ).10 Begitu pula muncul bahasa-bahasa A rab, bahasa Y aman Kuno dan bahasa Habsyi. Bahasa Arab lahir dari sebuah rumpun bahasa yang bernama Semit, sebelum datangnya agama K risten, para peneliti tidak dapat menemukan apapun karena tidak ada bukti dokumen tertulis berupa teks-teks. K elangkaan teks-teks A rab itu karena meluasnya buta huruf ('ummiyyah) dikalangan bangsa arab sebelum Islam datang. Namun tidak berarti sebelum datangnya agama Kristen bahasa A rab belum ada. Tidak pula berarti bahwa bahasa A rab lebih mudah dibanding dengan bahasa '/brani dan bahasa-bahasa Semit lain. Bahasa A rab mewarisi dan memelihara unsur-unsur bahasa bahasa Semit asal, berbeda dengan bahasa 'Ibrani sangat banyak memperbaharui diri dan itu semakin menjauh dari persamaan dengan bahasa Semit asal. ${ }^{11}$

Bahasa Arab sama halnya dengan bahasa-bahasa Yaman Kuno, bahasabahasa Habsy Semit adalah berasal dari satu induk yang sama yakni bahasa bangsa Semit yang berdiam disebelah selatan, tepatnya diwilayah Irak, dengan demikian 1962), h. 93.

${ }^{10}$ Lihat A li A bd. W ahid W afiy, I/mu al-L ugah (Cet. V; M ishra: Lajnah al-Bayaan al-'A rabiy,

${ }^{11}$ M ulyanto Sumardi, Ibid., h. 31. 
hubungan bahasa A rab dengan bahasa Semit sangat kuat. Lain halnya dengan bangsa Semit yang ada di utara sangat berbeda dengan bahasa A rab dari berbagai aspek, seperti asal-usul kata, A swaat dan qawaid-nya. Sedangkan bahasa-bahasa Yaman Kuno dan bahasa-bahasa habsy-Semit sangat kuat dan lebih dekat dengan bahasa Semit selatan dibanding dengan bahasa A rab.

Menurut Ali Abd al-Wahid Wafiy, informasi yang sempat terekam dalam sejarah dan sampai kepada kita tentang bahsa Arab adalah temuan dari prasasti tentang Arab Baidah yang diperkirakan hidup pada abad I sebelum masehi, sedangkan A rab Baqiyah, informasi yang ditemukan nanti setelah abad $\mathrm{V}$ masehi. Sehingga periodisasi pertumbuhan bahasa A rab sangat sulit untuk dilacak. ${ }^{12}$

Bahasa Arab secara tertulis masih sangat sedikit jika dibanding dengan bahasa yang lain, sehingga periodisasi bahasa Arab dan kesusasteraannya hanya terbatas pada zaman jahiliah, masa munculnya Islam yang dibawa oleh $\mathrm{Nabi}$ Muhammad Saw, masa Bani U mayyah, Bani A bbasiyah, kemunduran dan periode moderen. ${ }^{13}$ Dan yang diperpegangi oleh para ahli, tentang perkembangan bahasa A rab pada masa pra Islam (jahiliyah) adalah nukilah puisi-puisi yang dikembangkan pada zaman tersebut yang dipindahkan dari generasi kegenerasi. ${ }^{14}$

Dari hal di atas dapatlah dilihat pembagian bahasa A rab menjadi dua bagian yaitu:

\section{a. Bahasa A rab Baidah}

${ }^{12}$ Ali A bd A I-Wahid Wafiy, op.cit.

${ }^{13} \mathrm{~K}$ arl B roklaman, Tarikh al-A dab al-A rabiy, jilid I (Cet. IV ; al-Q ahirah Dar al-M a' arif, t.th), h. 30-38.

${ }^{14}$ Lihat M uhammad Suyuti Suhaib, Kajian Puisi A rab Pra Islam (Cet. I; Jakarta: A I-Q ushwa, 1990), h. 1-2. 
Bahasa A rab Baidah atau incrips adalah bahasa A rab prasasti, yang biasa juga disebut dengan istilah A rabiyah al-Nuqusy, karena informasi tentang bahasa ini hanya diperoleh melalui tulisan pada prasasti atau lempengan batu. Bahasa A rab Baidah yang berdiam disebelah utara Hijaz atau negeri yang berdekatan A ramiah, dialek bahasa yang dipergunakan dapat dibagi menjadi tiga bagian yaitu: pertama, dialek Lihyaniyah yang dinisbahkan dari nama kabilah atau suku Lihyan yang tinggal dibagian utara daerah Hijaz beberapa abad sebelum masehi. Para ahli berdeda pendapat tentang asal mula suku itu dan tanggal prasasti-prasastinya pun tidak diketahui secara pasti. Hanya diperkirakan prasasti tertua setelah abad ke II atau satu sebelum masehi, dan yang termuda sekitar abad ke VI masehi. Kedua, lahjah Samudiyah yang disandarkan kepada suku Samad sebenarnya yang dikisahkan di dalam al-Qur' an secara ringkas dalam perjanjian lama, baik Y unani maupun Roma, dan mahsyur didalam sejarah jahiliyyah. Suku ini diperkirakan mendiami wilayah antara Hijaz dan Nejed dekat Damaskus. Prasasti dalam bahasa Samud kira-kira abad ke III dan empat masehi. Ketiga, lahjah safawiyah, prasastinya didapati di daerah Shafa', walaupun ada juga yang terdapat didaerah lain di Harah yang terletak antara bukit dan gunung Daruz. Penulisannya diperkirakan antara abad ke III dan V I masehi. Orientalis Jerman, Enno Litman memperlihatkan bahwa rumus hurufhurufnya mendekati huruf Samad, huruf-huruf tersebut kadang-kadang dibaca dari kiri ke kanan atau sebaliknya. ${ }^{15}$

Ketiga dialek di atas berbeda dengan bahas fushah, namun dekat dengan bahasa bahasa Sam. Bahasa Arab Baidah juga ada kemiripan dengan bahasa A ramiyah, semua yang masuk dalam kategori baidah ini telah lenyap oleh dominasi

${ }^{15}$ Ali A bd. A I-W ahid W afiy, op. cit, h. 96-97. 
A rab Baqiyah.

\section{b. Bahasa A rab Baqiyah}

Bahasa A rab Baqiyah adalah bahasa yang masih dipakai oleh bangsa A rab dalam kesusasteraan, tulisan dan karangan. Bahasa ini tumbuh di negeri Hijaz dan Nejed, kemudian tersebar keseluruhan daerah daerah yang pernah memakai bahasa Semit dan Chamit, dari situlah timbul dialek-dialek yang dipergunakan pada masa kini dinegeri-negeri Hijaz, Nejed, Y aman dan daerah-daerah disekitarnya seperti Emirat A rab, Palestina, Y ordania, Syiriah, Libanon, Irak, K uwaid, M esir, Sudan, Libia, A I-J azair, M aroko, dan M alta. ${ }^{16}$

Bahasa A rab yang dipergunakan oleh orang-orang A rab sekarang atau yang terdapat dalam al-Qur' an dan hadis Nabi mulanya hanya tumbuh dan berkembang di wilayah $\mathrm{N}$ ejed dan Hijaz, namun selanjutnya menyebar ke berbagai daerah, seperti yang telah disebutkan, itu karena adanya Islam yang memberikan pengaruh yang sangat luas terutama setelah diadakan perluasan wilayah kekuasaan. Bahasa A rab B aqiyah dipakai dalam pergaulan sehari-hari, berdagang, bermasyarakat dan dalam pemerintahan. Bahasa Arab ini bisa bertahan dan tidak lenyap seperti saudarasaudaranya-baca: yang serumpun- adalah tidak lepas dari pengaruh dan peran Islam saat itu. Dimana ajaran utama Islam, al-Qur' an menggunakan bahasa A rab B aqiyah. Dengan sendirinya kaum muslimin waktu itu berusaha mengetahui bahasa A rab, bagi yang bukan penutur bahasa Arab Baqiyah yang selanjutnya bahasa Arab menjadi warna dalam pergaulan mereka sehari-hari. Sehingga bahasa-bahasa sebelumnya yang juga diapakai tidak lagi dipergunakan, disamping faktor agama juga faktor politik, otomatis bahasa lainnya akan mati dengan sendirinya karena

16 Ibid., h. 103. 
tidak ada lagi pemakainya. Dalam teori bahasa diakatakan bahwa suatu bahasa bisa hidup jika dihidupkan oleh penuturnya dan sebaliknya ia akan mati disaat ia ditinggalkan oleh penuturnya (tidak dipergunakan lagi sebagai bahasa Komunikasi). ${ }^{17}$

Para pengguna bahasa A rab di seputar jazirah A rab mempunyai dialek yang bermacam-macam diantaranya dialek Quraiys, Huzail, Saqil, hawasin, Kinanah, Taman dan $Y$ aman. ${ }^{18}$ Dialek-dialek ini terus dipergunakan hingga datang Islam bahkan masing-masing suku menggunakan dialek mereka disaat membaca al-Q ur' an hingga akhirnya K halifah Usman bin Affan menyatukan bacaan umat dalam satu lahjah yakni lahjah Quraiys, penyatuan bacaan umat pada waktu itu dengan lahjah Quraiys karena kota M akkah, dimana dialek Quraiys yang dipakai mempunyai letak geografis yang cukup strategis dibanding daerah lainnya, begitu juga Makkah menjadi kota religius dimana Nabi M uhammad SA W. dilahirkan dan tempat untuk umat Islam melaksanakan ibadah haji, dan tentu saja pertemuan antara dialek pun terjadi, namun dialek (lahjah) Quraiys tetap jadi pedoman.

A I-Qur'an sebagai bahasa standar diterima dan dicintai oleh masyarakat awam karena selain mempunyai makna yang dalam, juga susunannya sangat indah dan bagus, hal ini menjadi aset terjalinnya antara bahasa A rab dengan Islam yang selanjutnya dijadikan sebagai bahasa agama dan budaya Islam.

Pada masa pemerintahan U mar (13-23H) daerah kekuasaan Islam semakin meluas maka bercampurlah antara pendatang (orang A rab) dengan penduduk asli,

${ }^{17}$ Lihat Mahmud Kamil al-Naqah, Ta'lim al-L ugah al' A rabiyah li al-natiogin bi Lugat Ukhra Ushuluhu M udaakhiluhu, Turuqu Tadrisihi (M akkah al-M ukarramah: Jami' ah U mm al-Qura, 1985), h. 13.

${ }^{18}$ M anna' al-Qattan, Mabahis Fi 'Ulum al-Qur'an (Cet. II; t.tp, M asyurat al-A sr al-Hadis, t.th), h. 158. 
namun pendatang masih terisolir. Namun pengisolasian ini menumbuhkan persatuan diantara sesama pendatang yang berkelanjutan dengan persaingan dalam pergolakan ilmu bahasa, dan bahasa Arab sebagai bahasa pemenang sudah barang tentu mempunyai kedudukan yang mulia dan terhormat.

Pada masa pemerintahan Bani Umayyah, pendatang mulai berasimilasi dengan penduduk asli di seluruh lapisan masyarakat mulai dari pemerintahan sampai kepada budak. Dengan hasil asimilasi ini menghasilkan bahasa baru yang merupakan perpaduan dari bahasa Arab dengan bahasa setempat. Walaupun bahasa baru ini muncul, namun bahasa A rab masih tetap dalam kelas arsitokrat (kelas mewah).

Pada masa U mayyah ini, ketinggian martabat sosial seseorang ditentukan oleh kemampuan mereka dalam penguasaan bahasa A rab, kesalahan kecil dalam berbahasa dianggap sebagai kesalahan besar/fatal bagi orang-orang tua mereka, maka wajar jika setiap orang menginginkan setiap putra-putrinya menguasai bahasa A rab dengan mengirim belajar bahasa pada bangsa Badui. Namun, pada masa pemerintahan bani Abbasiyah, para pembesar tidak mengirim lagi putra-putri mereka untuk belajar lansung ke-orang-orang B adui, tapi hanya belajar bahasa A rab di istana, karena sebuah pemikiran agar anak-anak mereka bisa menikmati kemewahan kerajaan dan bisa berbahasa A rab dengan baik dan benar.

Pada akhir pemerintahan Bani U mayyah, mereka melakukan pemurnian bahasa A rab yang selanjutnya dilanjutkan pada masa $A$ bbasiyah baik orang-orang A rab maupun non A rab.

Rujukan utama bahasa Arab khusus gramatikalnya pada masa A bbasiyah adalah orang-orang B adui, karena mereka memandang bahwa hanya orang B adui lah yang memiliki keaslian bahasa itu. 
Disisi lain, bahasa kelas menengah kebawah yang kita kenal sebagai bahasa Ammiyah (yang merupakan percampuran antara bahasa Arab dengan bahasa setempat) mulai tumbuh dan lansung membludak, dimana pada abad ke III pengaruh A mmiyah sangat kuat, sampai ditemukan dalam tulisan-tulisan ilmiyah banyak yang mempergunakan bukan bahasa A rab asli.

Pada abad ke IV hijriah, orang-orang tidak lagi belajar lansung kepada orangorang Badui, tetapi hanya lewat karangan-karangan Badui yang sudah banyak di pasaran buku-buku. ${ }^{19}$ Bahasa A rab - baca: fusha- di abad inimasih menjadi bahasa administrasi, politik dan lain-lain, namun pada abad ke V, bahasa A rab hanya sebagai bahasa agama saja. Dimana para karangan para cendekia kadang menggunakan bahasa Persia.

M inat untuk mempelajari bahasa al-Qur'an ini terus terkikis hingga abad ke VI. Kemerosotan ini bersamaan dengan munculnya kaum Saljuk dan berhasilnya bangsa M ongolia menduduki negara-negara Islam. Dan salah satu Negara yang tak sempat diduduki adalah M esir, yang nantinya merupakan tempat kebangkitan bahasa A rab di zaman baru.

Sebagaimana kita maklumi, bahwa bahasa A rab Baqiyah adalah bahasa yang digunakan dalam bahasa tulisan, dan bahasa sastra yang sampai kepada kita melalui syair Jahiliyah, al-Qur'an dan al-Sunnah al-Nabawiyah, yang selnjutnya disebut dengan bahasa Arab fushah. Bahasa fushah tersebut bukanlah semata-mata hanya dialek Quraisy, tetapi merupakan perpaduan dari berbagai dial ek bahasa A rab. ${ }^{20}$

Dalam buku Fusul fi Figh al-L ughah, DR. Ramdan Tawwab menyebutkan

${ }^{19}$ Lihat M ulyanto Sumardi, op. cit, h. 34-48.

20 Lihat Dr. Muhammad A hmad Abu al-Faraj, Muqaddimah Li Dirasah Fiqh al-Lughah (Beirut: Dar al-Nahdah al-A rabiyah, t.th), h. 91. 
bahwa, nama dialek bahasa A rab sebanyak 19.21 Dalam makalah ini, penulis tidak menjelaskan satu demi satu dialek tersebut, namun, penulis dapat menyimpulkan bahwa, kabilah-kabilah A rab yang memiliki bahasa yang fasih ada tiga macam, yaitu Tamim, Ta'i, dan Huzail. Mereka inilah yang terkenal kefasihannya dalam berbahasa, dan bahasa mereka menjadi bahasa standar, yaitu bahasa yang digunakan dalam berinteraksi sehari-hari, bahasa yang digunakan dalam menulis syair, dan bahasa pengantar dalam interaksi perdagangan. ${ }^{22}$

B ahasa arab fushah terkadang juga dinisbahkan kepada dialek dominan dari seluruh dialek yang ada, karena adanya empat faktor yaitu; ekonomi, politik, sosial dan agama. ${ }^{23}$ Setelah bahasa Arab Fusha semakin menipis peminatnya, maka muncullah bahasa A mmiyah sebagai penggantinya, namun ini pun tak bisa bertahan dengan arus percampuran bangsa-bangsa asing yang tidak disadari sedikit demi sedikit merasut ke dalam bahasa A mmiyah, dan dipakai dalam masyarakat hingga kini.

\section{Kesimpulan}

Dari uraian yang telah dikemukakan terdahulu tentang $A$ sal Usul Bahasa Arab, pertumbuhan dan pembagiannya, dapat disimpulkan bahwa, Bahasa Arab adalah salah satu cabang dari sekian banyak cabang bahasa Semit yang telah berkembang sejak ribuan tahun. Bahasa A rab muncul sebagai bahasa yang berdiri

${ }^{21}$ Lihat DR. Ramadan Abdul Tawwab, Fusul fi Figh al-Lughah (Cet. II; al-Qahirah: M aktabah al-Haniji, 1980), h. 120-152.

${ }^{22}$ Lihat Shubhi Shalih, Dirasat fi Fiqhi al-A rabiyah (Cet. II; B eirut: M ansyurat al-M aktabah al-A halliyah, 1962 M/1382 H), h. 58.

${ }^{23}$ Lihat Shubhi Shalih, op. cit., h. 50-59. 
sendiri, karena salah satu dari pengguna bahasa Semit awal melakukan perpindahan ke daerah-daerah lainnya, Ialu membentuk bangsa sekaligus bahasa.

Proses evolusi yang terjadi dalam pergolakan bahasa A rab dengan bahasabahasa setempat menjadikan bahasa A rab asli menjadi bermacam-macam dialek, yang serta merta dipergunakan seseorang, dan akhirnya memasyarakat tanpa disadari dan dirasakan lansung oleh si pengguna bahasa itu.

Bahasa Arab yang mendiami Nejed dan Hijaz mempunyai dua kelompok bahasa, yaitu Baidah dan Baqiyah. Baidah adalah merupakan bahasa yang telah terkubur dengan masa, sedangkan Baqiyah adalah bahasa yang dipergunakan oleh masyarakat jahiliyah sampai zaman kita sekarang.

Bahasa A rab dapat tumbuh berkembang dan berdiri sendiri, disebabkan karena banyak faktor pendukungnya, diantaranya pergaulan dan percampur-bauran antara bangsa-bangsa, juga didukung oleh berbagai unsur yang sangat potensial mengembangkan bahasa A rab. 


\section{DAFTAR PUSTAKA}

A /-Qur'anul Karim

A bdul Tawwab, Ramadan. Fusul fi Fiqh al-L ughah. Cet. II; al-Qahirah: M aktabah alHaniji, 1980.

A I-Faraj, M uhammad A hmad A bu. M uqaddimah Li Dirasah Fiqh al-L ughah. Beirut: Dar al-Nahdah al-A rabiyah, t.th.

Al-Naqah, Mahmud Kamil. Ta'lim al-Lugah al' A rabiyah li al-natioqin bi Lugat Ukhra Ushuluhu M udaakhiluhu, Turuqu Tadrisihi. Makkah al-M ukarramah: Jami'ah Umm al-Qura, 1985.

Al-Qattan, M anna'. Mabahis Fi 'Ulum al-Qur'an. Cet. II; t.tp, M asyurat al-A sr alHadis, t.th.

Ali, K. "a study of Islamic History", diterjemahkan oleh G hufran A. M as' adi dengan judul Sejarah Islam dari A wal Hingga Runtuhnya dinasti Usmani, Tarkh Pra Moderen, ed I. Cet. I; J akarta: Raja Grafindo Persada, 1997

Al-W afiy, A li A bd. I/mu al-L ugha. Cet. V; M isra: Lajnah al-B ayan al-A rabiy, 1962.

Broklaman, Karl. Tarikh al-Adab al-A rabiy, jilid I. Cet. IV; al-Qahirah Dar alMarif, t.th.

Cahyono, Bambang Y udi. Kristal-Kristal I/mu Bahasa. Cet. I; Surabaya: A irlangga University Press, 1995.

Hitti, Philip K. "The Arab Short History", diterjemahkan oleh Ushuluddin Hutagalung dan O.D.P. Sihombing dengan judul Dunia Arab. Cet. III; Bandung: Sumur Bndung, t.th.

Shalih, Shubhi. Dirasat fi Fiqhi al-A rabiyah. Cet. II; B eirut: M ansyurat al-M aktabah al-A halliyah, $1962 \mathrm{M} / 1382 \mathrm{H}$. 
Jurnal Iqra’ Vol.5. No.1, Januari - Juni 2011

Sumardi, M ulyanto et.el, Pedoman Pengajaran Bahasa A rab Pada Perguruan Tinggi Agama Islam IAIN. Jakarta: Proyek Pengembangan Sistem Pendidikan A gama, Departemen A gama RI, 1975.

Suyuti Suhaib, Muhammad. Kajian Puisi A rab Pra Islam. Cet. I; Jakarta: AlQushwa, 1990.

U mam, Chatibul. A spek-aspek Fundamental Dalam Bahasa A rab. Cet. 1; B andung: PT A Imaarif,1980.

et.el. Pedoman Pengajaran Bahasa Arab Pada Perguruan Tinggi A gama IA IN. Jakarta Proyek Pengembangan Sistem Pendidikan A gama RI, 1975. 